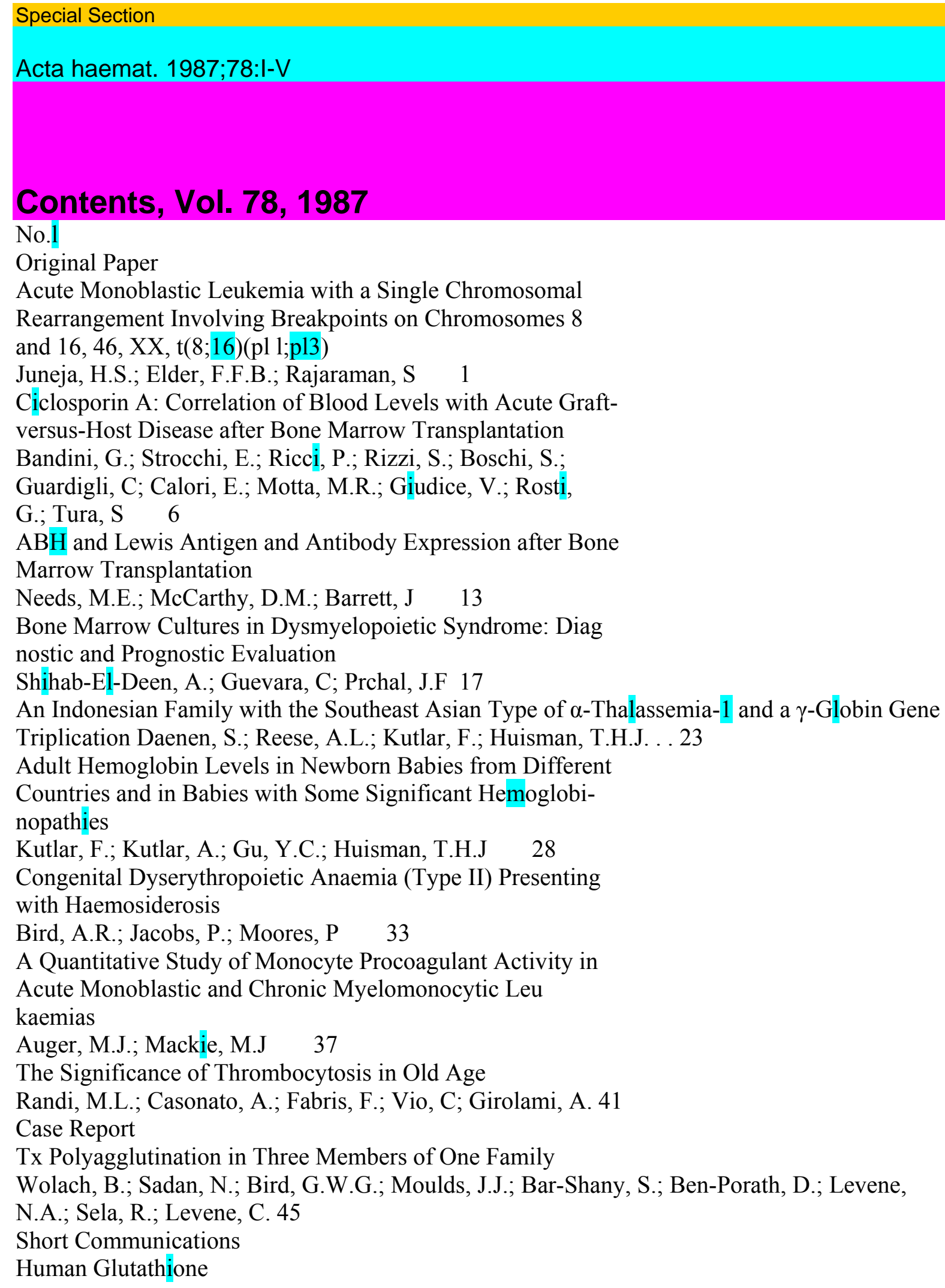

Acta haemat. 1987;78.I-V

\section{Contents, Vol. 78, 1987}

No.1

Original Paper

Acute Monoblastic Leukemia with a Single Chromosomal

Rearrangement Involving Breakpoints on Chromosomes 8

and $16,46, \mathrm{XX}, \mathrm{t}(8 ; 16)(\mathrm{pl} 1 ; \mathrm{pl} 3)$

Juneja, H.S.; Elder, F.F.B.; Rajaraman, S 1

Ciclosporin A: Correlation of Blood Levels with Acute Graftversus-Host Disease after Bone Marrow Transplantation Bandini, G.; Strocchi, E.; Ricci, P.; Rizzi, S.; Boschi, S.;

Guardigli, C; Calori, E.; Motta, M.R.; Giudice, V.; Rosti,

G.; Tura, S

6

$\mathrm{ABH}$ and Lewis Antigen and Antibody Expression after Bone

Marrow Transplantation

Needs, M.E.; McCarthy, D.M.; Barrett, J 13

Bone Marrow Cultures in Dysmyelopoietic Syndrome: Diag

nostic and Prognostic Evaluation

Shihab-El-Deen, A.; Guevara, C; Prchal, J.F 17

An Indonesian Family with the Southeast Asian Type of $\alpha$-Thalassemia- 1 and a $\gamma$-Globin Gene

Triplication Daenen, S.; Reese, A.L.; Kutlar, F.; Huisman, T.H.J. . . 23

Adult Hemoglobin Levels in Newborn Babies from Different

Countries and in Babies with Some Significant Hemoglobi-

nopathies

Kutlar, F.; Kutlar, A.; Gu, Y.C.; Huisman, T.H.J 28

Congenital Dyserythropoietic Anaemia (Type II) Presenting

with Haemosiderosis

Bird, A.R.; Jacobs, P.; Moores, P 33

A Quantitative Study of Monocyte Procoagulant Activity in

Acute Monoblastic and Chronic Myelomonocytic Leu

kaemias

Auger, M.J.; Mackie, M.J 37

The Significance of Thrombocytosis in Old Age

Randi, M.L.; Casonato, A.; Fabris, F.; Vio, C; Girolami, A. 41

Case Report

Tx Polyagglutination in Three Members of One Family

Wolach, B.; Sadan, N.; Bird, G.W.G.; Moulds, J.J.; Bar-Shany, S.; Ben-Porath, D.; Levene,

N.A.; Sela, R.; Levene, C. 45

Short Communications

Human Glutathione 
Immunological Cross-Reactivity of S-Transferases from Blood Cells Yoshizaki, Y.; Fujii, S.;

Kaneko, T.

48

Spontaneous Formation of Megakaryocyte Progenitors (CFU-

MK) in Primary Thrombocythaemia

Han, Z.C.; Brière, J.; Abgrall, J.F.; Sensèbe, L.; Nedellec,

G.; Parent, D.; Guern, G 51

Glycosylated Hemoglobin in Saudi Sickle Cell Patients with

Glucose-6-Phosphate Dehydrogenase Deficiency

Alayash, A.I.; Dafallah, A.; Wilson, M.T 54

Correspondence

Effect of Sample Storage on the Assay of Erythrocyte Proto-

porphyrin by the Hematofluorometer Method

Galan, P.; Mekki, N.; Hercberg, S 57

Clinical Outcome of HIV Infection

Falutz, J.; Tsoukas, C 59

Nuclear Protrusions and Marker Chromosomes in Lympho

cytes of Two Patients with Cutaneous T-Cell Lymphoma

Emilia, G.; Torelli, G.; Sacchi, S.; Zucchini, P.; Selleri, L.;

Temperani, P.; Torelli, U 61

Familial Thrombocythemia and/or Thrombocytosis - Appar

ently a Rare Disorder

Randi, M.L.; Fabris, F.; Vio, C; Girolami, A 63

Book Reviews $\quad 64$

No. 2-3

Haemoglobin

Research and Application

Obituary

Weatherall, D.J 69

Professor Hermann Lehmann: A Personal Tribute

Huntsman, R.G 71

Molecular Variation

Has Haemoglobin a Future?

Weatherall, D.J 74

Life among the Hemoglobins

Schneider, R.G $\quad 75$

A Short Review of Human $\gamma$-Globin Gene Anomalies

Huisman, T.H.J 80

IV

Contents

Structure, Function

X-Ray Crystallographic and Functional Studies of Human

Haemoglobin Mutants Produced in Escherichia coli

Luisi, B.F.; Nagai, K.; Perutz, M.F 85 
Deformability of the Hemoglobin Molecule as the Basis of Its

Functional Behavior

Winterhalter, K.H.; Di Iorio, E.E 90

Structure, Physiology

Reduction and Spectroscopic Properties of Hemoglobins M

Nagai, M.; Takama, S.; Yoneyama, Y

Modification of Hemoglobin with Site-Directed Bifunctional

Reagents

Kavanaugh, M.P.; Shih, D.T.-B.; Jones, R.T 99

Role of Membrane-Bound Haemoglobin Products in Oxida-

tive Damage in Sickle Cell Membranes

Rice-Evans, C; Baysal, E 105

Diagnosis, Distribution

Structure and Function of a New Hemoglobin Variant, $\mathrm{Hb}$

Meilahti (c⿺𠃊1/8 WS \&gt; Pro $\rightarrow$ Thr $^{\wedge}$ Characterized by Mass Spec-

trometry

Wada, Y.; Ikkala, E.; Imai, K; Matsuo, T.; Matsuda, H.;

Lehtinen, M.; Hayashi, A.; Lehmann, H. † 109

Neonatal Screening and Mass-Spectrometric Analysis of Hemoglobin Variants in Japan

Hayashi, A.; Wada, Y.; Matsuo, T.;Katakuse, I.; Matsuda, H. 114 Characterization Approach

of'Silent' Beta-Chain Hemoglobin

Variants

Lacombe, C; Riou, J.; Godard, C; Rosa, J.; Galacteros, F. 119 High-Performance Liquid

Chromatography as a Method to

Identify Haemoglobin Abnormalities

Huisman, T.H.J $\quad$. 123

Strategy for Structural Characterization of Haemoglobin

Variants

Baudin-Chich, V.; Rochette, J.; Wajcman, H 127

Haemoglobinopathies, Thalassaemias and Enzymopathies in

Saudi Arabia: The Present Status

El-Hazmi, M.A.F 130

Haemoglobin Disorders among Southeast-Asian Refugees in

France

Dode, C; Berth, A.; Bourdillon, F.; Mahe, C; Labie, D.;

Rochette, J 135

Screening

Prenatal Diagnosis of Hematologic Diseases, 1986 Update

Alter, B.P

Neonatal Haemoglobinopathy Screening

Frost, B.A.; Bellingham, A.J 142

Haemoglobin A/F Ratio in Neonates at 7 Days Correlated with Birth Weight and Estimated

Gestational Age Thomas, S.; Drew, R.; Ersser, R.; Hjelm, M.; Stephens, A. 144

Haemoglobinopathy Screening in a 'Low-Risk' Area of the

United Kingdom: South Glamorgan, Wales

Bentley, D.P.; Cavill, I.; Choiseul, M.J.; Evans, D.; Hutton, 
R.D.; Jacobs, A.; Jobbins, K.; McLellan, D.; May, A.; Wal-

pole, B.S.; Wardrop, C.A 149

Thalassaemia

The Origin of Mutant $\beta$-Globin Genes in Human Populations

Wainscoat, J.S 154

Approach to the Diagnosis of B-Thalassaemia by DNA Analysis

Thein, S.L.; Weatherall, D.J 159

Prevention of Thalassaemia and Haemoglobin S Syndromes in

Greece

Fessas, P 168

$\alpha$-Thalassaemia and the Malaria Hypothesis

Hill, A.V.S.; Flint, J.; Weatherall, D.J.; Clegg, J.B 173

Can Automated Haematology Analysers Discriminate Thalas

saemia from Iron Deficiency?

Marti, H.R.; Fischer, S.; Killer, D.; Bürgi, W180

Sickle Cell Disease

Genetic Heterogeneity of Sickle Mutations

Labie, D.; Nagel, R.L 184

Avascular Necrosis of the Femoral Head in Sickle Cell Syn

drome: A Report of 5 Cases

Rand, C; Pearson, T.C.; Heatley, F.W 186

Clinical Management of Severe Sickle Cell Disease

Yardumian, A.; Davies, S.C 193

Transfusion and Exchange Transfusion in Sickle Cell Anae

mias, with Particular Reference to Iron Metabolism

Porter, J.B.; Huehns, E.R 198

Iron Overload and Iron Chelation Therapy in Thalassaemia

and Sickle Cell Haemoglobinopathies

Pippard, M.J 206

Iron Overload

Orally Active Alpha-Ketohydroxypyridine Iron Chelators:

Effects on Iron and Other Metal Mobilisations

Kontoghiorghes, G.J 212

In vivo Evaluation of Hydroxypyridone Iron Chelators in a Mouse Model

Gyparaki, M.; Porter, J.B.; Hirani, S.; Streater, M.; Hider,

R.C.; Huehns, E.R 217

Abstracts 222

Author Index 224

No. 4

Original Paper

Trinitrophenyl-Derivative of Urinary Trypsin Inhibitor: A Strong Antifibrinolytic Agent

Sumi, H.; Hamada, H.; Maehara, S.; Yoshida, E.; Tsushi

ma, H.; Maruyama, M.; Mihara, H 225

Motility of Leukemic Cells in Collagen Gel Related to Immu-nological Phenotype in Childhood Acute Lymphoblastic Leukemia 
Hogeman, P.H.G.; Veerman, A.J.P.; Huismans, D.R.; Van

Zantwijk, C.H.; Bezemer, P.D 229

Short Course Intermediate Dose Intravenous Melphalan Therapy in Myeloma - Relation to Early

Emergence of Drug Resistance (Phase II Study) Sviland, L.; Leggat, H.; Harris, A.L.; Bird, G.;

Proctor, S.J. 233

Contents

$\mathrm{V}$

Lack of Correlation between Plasma Cell Thymidine Labelling

Index and Serum Beta-2-Microglobulin in Monoclonal

Gammopathies

Boccadoro, M.; Durie, B.G.M.; Frutiger, Y.; Gavarotti, P.;

Redoglia, V.; Massaia, M.; D’Alberto, M.; Marmont, F.;

Gallamini, A.; Tribalto, M.; Pileri, A 239

Immunological Profile after Splenectomy in Children with B-

Thalassaemia Major

Mandalenaki-Lambrou, K.; Vrachnou, E.; Calogeropou-

lou, C; Ladis, V.; Kattamis, C243

A Paucity of Thalassemia Trait in Italian Men with Myocar-

dial Infarction

Crowley, J.P.; Sheth, S.; Capone, R.J.; Schilling, R.F. . 249 Alcohol-Induced Bone Marrow

Damage. A Bone Marrow

Study in Alcohol-Dependent Individuals

Michot, F.; Gut, J 252

Case Report

Acquired von Willebrand's Syndrome Due to an Inhibitor of

IgG Specific for von Willebrand's Factor in Polycythemia

rubra vera

Möhri, H.; Ohkubo, T 258

Correspondence

Deficiency of Eosinophil Peroxidase Detected by Automated

Cytochemistry

Valdés, M.D.; Calero, M.A 265

Book Reviews 266

Author Index 268

Subject Index 269

Suppl. 1

Hemato-Oncology and Hemato-Immunology

2nd Sicilian International Conference

Catania, Italy, November 25-29, 1986 Editor: Elio Cacciola, Catania 